\title{
The Impact of Immediate and Delayed Corrective Feedback on Iranian EFL Learners' Willingness to Communicate
}

\author{
Mahtab Zadkhast (Corresponding author) \\ Department of ELT, Kermanshah Science and Research Branch, Kermanshah \& Department of ELT, College of Literature and Humanities, \\ Kermanshah Branch, Islamic Azad University, Kermanshah, Iran \\ E-mail: mahtab.zadkhast@gmail.com \\ Majid Farahian \\ Department of ELT, College of Literature and Humanities, Kermanshah Branch, Islamic Azad University, Kermanshah, Iran \\ E-mail: farahian@iauksh.ac.ir
}

Received: 18-03-2017

Published: 01-11-2017
Accepted: 17-05-2017

doi:10.7575/aiac.ijalel.v.6n.6p.28
Advance Access Published: September 2017

URL: http://dx.doi.org/10.7575/aiac.ijalel.v.6n.6p.28

\begin{abstract}
The present study investigated the impact of immediate and delayed corrective feedback on Iranian EFL learners' willingness to communicate. To attain the purpose of the study, 45 females intermediate students that were roughly selected according to their previous grades and their assigned level in language school were chosen to participate in this study. Then they were divided to three equal groups: Experimental group 1(immediate feedback), Experimental group 2 (delayed feedback) and control group. In the first session, WTC questionnaire (MacIntyre ,2001 modified by Pourya Baghaei and Ali Dourakhshan) was administered to all groups as pretests. In group 1 the students' errors were corrected by the teacher immediately after committing but in the second group, the students' errors were written by the teacher and her comments were given to them when they finished their tasks. For the control group, the routine procedure of New Headway intermediate was followed. After about 12 sessions WTC was repeated as posttests. The findings revealed that immediate and delayed corrective feedback have a significant effect on EFL students' level of WTC. The results, also demonstrated that experimental group 1 (immediate feedback) outweighed the other two groups in relation to their WTC. The findings have implication for pedagogy as well as further research.
\end{abstract}

Keywords: Immediate and Delayed Corrective Feedback, Willingness to Communicate, EFL learners

\section{Introdution}

During the history of language teaching, a growing body of research has been concerned with the importance of speaking skill. The reason for such an emphasis is laid in the general view over language learning which is confined to knowing how to speak. In other words, it seems that the focus on language and communication is the major criterion for foreign language (FL) learning (Wang, 2005). Accordingly, FL instructors never stopped searching and developing better ways for reaching more effective teaching goals, accessing authentic materials, and providing techniques that benefit their students' knowledge and enhance their skills specifically speaking (Wang, 2005). Considering speaking ability as a crucial aspect of language learning experience, one of the areas in which language learners face problems in language classroom is their reluctance to communicate.

By now, it is accepted that in the process of FL learning both cognitive and affective domains should be optimally activated. In some situations, after speaking, some learners learning English and having a presumably high level of language competence are still reluctant to interact (MacIntyre, 2007). Such communication dislike displayed by these learners might show that there must be an elusive variable which can put that competence into practice and make the individual more responsive, leading to the actual and volitional initiation of second language (L2) communication (Dörnyei, 2005). This elusive variable that seems to have an important effect on the speaking ability of the learners is their level of willingness to communicate( WTC). According to MacIntyre, et al (2002), WTC is defined as "an underlying continuum representing the predisposition toward or away from communicating, given the choice" (p.538). As WTC is an affective factor, it can be claimed that the role of teacher in classroom may have direct effect on language learners' WTC. This variable which is in close connection with communicative reluctance may be laid in teachers' behavior in the classroom.

Additionally, a large part of teachers' behavior in the classroom is allocated to error treatment. Thus, in the FL classrooms, language errors and corrective feedbacks comprise a large part of the teaching-learning process. Corrective feedback is a signal to a learner that his or her use of the target language is incorrect, and includes different responses that a language learner receives (Lightbown \& Spada, 1999). Based on the aforementioned definition, if we consider corrective feedback as a signal, the teacher is responsible of sending this signal; therefore, it seems that the way the 
English as foreign language( EFL) teacher sends this signal may affect EFL learners' WTC and therefore their classroom interaction.

Communicating and speaking with others in English classrooms is a problematic issue for many language learners. As we know, the main aim of learning a second language is for communicating in that language and this is a prominent role of FL learning. So we should look for the reasons of this problem. In other words, the comparison between students' willingness to communicate when they receive immediate or delayed corrective feedback can be one of the helpful ways to overcome these difficulties and a good guide for teachers to apply appropriate corrective feedback in their classrooms for getting better pedagogical results.

In recent decades, the emphasis on L2 teaching and learning has shifted to communication and therefore, both as a necessary process and as a goal of learning an L2, it is needed that a way to consider individual differences in L2 communication be investigated. One of the area which received little attention was WTC. The main focus of the present study was on language learners' WTC. WTC is a recent trend in what seems to be affecting learners' L2 learning and it has drawn attention of the researchers to itself in accounting for individuals' L1 and L2 communication and learning.

If WTC is the ultimate goal of L2 instruction (Dörnyei, 2005), then unwillingness to communicate may be supposed as a barrier to communicate and any reason for this unwillingness such as anxiety, demotivation, not supporting teacher talk, etc. may be increased. Therefore, students' silence in the classroom may result in crucial problems in learning process. Over the last two decades, second language acquisition (SLA) researchers such as MacIntyre et al (2002) have all emphasized the importance of willingness to communicate as a crucial component of modern language instruction. So, it can be claimed that the notion of WTC, which is actually the intention and desire to initiate communication, plays a key role in learning a second/foreign language. Furthermore, communicative tasks enable learners to speak freely without teacher's pressure, classmate's stresses, and some other factors threatening their fluency. One of the area which received little attention was WTC. The concept of WTC, defined as the probability of speaking when free to do so (McCroskey \& Baer, 1985; MacIntyre, Clément, Dörnyei \& Noels, 1998), helps to orient our focus toward a concern for " microlevel processes and the sometimes rapid changes that promote or inhibit L2 communication" (MacIntyre, 2007). Yashima \& Tanaka (2001) found that WTC affected the psychological adjustment of Japanese students who lived and studied in the United States for a time, because students who were more willing to speak to their host families learned more English, made more friends, and had a more positive experience than those with lower WTC.

Through communicative tasks, they can participate in classroom interaction which will provide language learners with the opportunity of real world exchanges. However, it seems that one of the issues which bars free communication is the way EFL teachers correct EFL learners' errors.

One of the questions that foreign language teachers most often address is what to do about error correction: how and when should they correct whom, if at all? Error correction is not only of practical importance, but is also a controversial issue in the SLA literature, where it is often included in the more general term 'negative evidence' in spite of the importance of the question. We have hardly an evidence for or against error correction during oral communicative activities in the second language classroom.

Therefore, this study can be beneficial for FL teachers who wonder how they can increase their students' WTC which will eventually lead to better learner-learner and learner-teacher interaction, and therefore better L2 learning. On the other hand, teachers can benefit from the findings of this study, which attempts to find out what kind of feedback or error correction gives way to educating L2 learners with a high rate of WTC and which type of error correction does not seem to contribute to increasing learners' WTC. Having such perspective in mind, the present study was an attempt to investigate the effect of immediate and delayed corrective feedbacks on Iranian female EFL learners' willingness to communicate.

\section{Literature Review}

\subsection{Communicative Language Teaching (CLT)}

The intended outcome of these methodologies is meaningful student-student interaction, which research has shown creates learning opportunities and facilitates the second language acquisition process (Long, 1983). However, for CLT to be effectively implemented, students need to have WTC (MacIntyre, Baker, Clément, \& Conrod, 2001).

Task-based teaching and other popular pedagogical proposals that fall under the umbrella of CLT are useful in that they promote classroom interaction. However, interaction can only happen if students consider this learning environment beneficial (McCroskey \& Richmond, 1987). Past research (Aubrey, 2009; Littlewood, 2000) has indicated that Asian students respond positively to CLT under certain conditions. Aubrey (2010) states that "Of particular interest to teachers is the finding that having a more positive attitude towards CLT is essential for producing an ideal classroom situation". (p. 42)

\subsection{Speaking}

In communicative era of language teaching, speaking gained an important position among other skills. As Egan (1999) states, speaking skill is the main component of second language teaching and learning but in recent years, it has been neglected for a number of reasons. In Teaching English as a Foreign Language (TEFL), speaking is considered as an interactive productive skill which focuses on receiving, processing and transferring intended meanings in spoken form of language. (McDonough \& Shaw 1993; Brown 1994). 
Accordingly, the main duty of speaker of every language is not only producing sounds but also employing language in order to interact successfully with the listener (Fulcher 2003). Beside these, there are two elements in our speech, first manifestation of sound waves and second expression of internal meanings through concentrating on the lexicogrammatical aspects of spoken and written form of language (Brown, 1994).

Accordingly, Levelt (1989) suggested four steps to observe those two elements in speech production:

- Conceptualization: encoding messages;

- Formulation: selection of lexical item;

- Articulation: psychophysiological mechanisms of speech production; and

- Self-monitoring: Identification and correction of mistakes

Levelt's model is clarifying different components of speaking skill in a way that a person produces speech sound individually while the nature of speaking skill is reciprocal. As Nunan (1991) argues speaking is an ability for human being in which there are conventional ways of transferring information, expressing our idea, and thought we have in our mind. In line with this view, Bashir, Azeem, and Dodger (2001) consider speaking as a skill which can be employed not only for merely expressing words through mouth, but also conveying the message through the words of mouth.

Concerning aforementioned points, assessing the nature of speaking skill indicates that it evolves through interpersonal interaction. Accordingly, the nature of speaking skill is cooperative. This collaboration among interlocutors leads to negotiation of meaning which is crucial for mutual understanding (Bygate, 1987). Negotiation of meaning becomes accessible if the interlocutors follow certain criteria in their speaking. These criteria are embedded in the following terms in TEFL, accuracy and fluency (Bygate, 1987). Now, to have an accurate view over the characteristics of speaking skill in the following parts, first we will review the differences between spoken and written form of language after that different characteristics of speaking skill i.e. accuracy and fluency will be presented.

\subsection{WTC and L2 Learning}

WTC was applied to L2 communication by MacIntyre and Charos(as cited in Kang, 2005). The significance of WTC in L2 acquisition comes from the important role that interaction plays in language acquisition, which has been justified from both linguistic and socio-cultural perspectives (Kang, 2005). Thus, WTC which is deemed to affect the frequency of interaction (Clement, Baker, \& MacIntyre, 2003) can contribute to SLA and is considered as an important component of modern L2 pedagogy (Macintyre et al., 1998).

Adapting WTC to L2 communication, MacIntyre et al (2001) suggested a theoretical heuristic model to show the role of both individual and contextual variables in WTC based on a combination of motivational and attitudinal factors. They considered WTC as a situational variable, which influences communication in the four language skills. The model which was presented in the shape of a multi-layered pyramid integrates various social-psychological, linguistic and communicative variables as precursors of L2 communication (Peng, 2007).

According to MacIntyre et al (2001) L1 WTC is not transferable to L2 communication; meaning that L1 WTC and L2 WTC are relatively independent. MacIntyre et al (2001) attributes this lack of transferability to the variation in communicative competence of L2 users and social factors related to the L2 communication situation.

Within the L2 acquisition context, it is not uncommon to see people with a high level of L2 communicative competence who tend to avoid communication (Yashima, 2002). This implies that L2 WTC function as a mediating layer between having the L2 competence and using this competence to communicate (Dornyei, 2005). The past decade has witnessed a growing body of research into L2 WTC (Clement, Baker, \& MacIntyre, 2003; Kang, 2005; MacIntyre, Baker, Clement, \& Conrod, 2001; Yashima, 2002).

These studies have mostly aimed at validating the complex nature of the WTC. Baker and MacIntyre (2000) compared L2 WTC in immersion vs. non-immersion learners. The result revealed significant situational differences. Immersion learners showed higher level of WTC and more frequent use of L2 for communication. Kang (2005) employed a qualitative approach to investigate situational variables influencing L2 WTC. She studied four Korean students studying in an American university for eight months. She found that their level of L2 WTC is a function of interaction among psychological variables of excitement, security and responsibility on one hand and situational variables including the interlocutors, the topic and the conversational context on the other hand.

Yashima and her colleagues` studies in Japan (Yashima, 2002) revealed that perceived communicative competence, L2 communication confidence, and communication anxiety are the most significant constitutes of L2 WTC. The result of several studies indicated that motivation to learn an L2 influences L2 WTC either directly or indirectly (Hashimoto, 2002; MacIntyre, et al. 2002). It was also found that L2 WTC is associated with personality traits ( MacIntyre et al., 1996), gender ( Baker and MacIntyre, 2000; MacIntyre, 2002) and social support ( MacIntyre, Baker, Clement and Conrod, 2001).

\subsection{Feedback}

EFL teacher traditionally emphasizes a kind of correction of every learner's errors firmly, while nowadays, he gives more focus on the learners' reaction to his provided feedback to solve learners' problems which are shown through the ambiguity of the conveying message.' Feedback usually refers to the learners' response given to the teachers spoken or written output'(Duly, Bust \& Krashen,2006). This indicates that feedback refers to the information or suggestion that the teacher as a listener or as reader gives or provides to his learners speaking performance or written production.A 
definition suggested by (Mory, 2002):' Feedback is the information presented to the learner after any input with the purpose of forming the concept of input of the learner''(p.7).Morover,he states that feedback determines the comparison between the learners and the teachers intended answer.According to MCDonough(2007) they demonstrate two main parts of feedback: assessment and correction, assessment is presented through providing information on how the learner performs his/her tasks while the correction is the fact of describing the learners committed errors when performance through giving information on what is wrong or right.

\subsection{Types of Feedback}

Teachers' feedback can be done in different ways. In the following parts various aspects of oral feedback will be reviewed.

\subsubsection{The Oral Feedback}

According to Frey and Fisher (2004) "it happens basically in spoken language. In order to achieve significant learning output, the oral feedback should be accompanied by the setting characteristics, the structure, and the tone" (p.9). These aforementioned points are of great importance to student when receiving the oral feedback.

The setting is selected in the classroom according to some extents: "it gives learners a place to concentrate on what is being said and to determine the tone in which it is delivered" (Richards, 2006, p.8). If the teacher's feedback is brief, teacher should close to the student and lower his voice in order to move smoothly in the conversation. This type of feedback helps the learner to get it.

Through effective oral feedback, the teacher should be specific and should demonstrate the learner to which is correct or not. There are three parts of the structure for academic feedback:

- Showing the result of learner's performance.

- Describing and distinguishing between the right form and the wrong form that should be changed.

- Motivating and encouraging to centime.

- Use the supportive form

Harmer (2004) claims that the teacher's feedback is helpful during the oral tasks, in which the teachers should react to their learners' performance in different way; the helpful feedback based mainly on the stage of lesson, the activity, the type of committed errors, and the particular receiver of the feedback. So, he suggests two situations of feedback.

According to Harmer (2004), it can be done by different ways:

- Repeating: by asking students to repeat what they have said.

- Echoing: it is a precise way of pin-pointing an error through emphasizing the incorrect utterance's part; for example, through uttering the wrong part as questioning intonation.

- Statement and question: by indicating or demonstrating that a part of the utterance is not correct.

- Expression: by using the simple facial expressions and gestures to indicate how the utterance is worked, but it should have done when the teacher knows his class well.

- Hinting: by giving a hint to the wrong part in order to apply the known rules

- Reformulating: correcting the learner's utterance through reformulating what he said (pp. 106-107).

\subsection{Advantages of Cooperative Learning}

Cooperative learning strategies may be especially favorable in college courses which controlled the traditional lecture forms that have the least students' discussions. Incorporating cooperative learning processes may allow learners to become active participants in the learning process and lead them to think and comprehend the materials in the best ways (Ebert- My, Brewer, \& Allred, 1997 as cited in Carrol, Williams, \& Hautau, 2005).

Cooperative learning considers the instruction in schools' lessons and the formation of heterogeneous groups. These methods are structured, organized and instructional strategies which are applied at any level of the learners and in most school subjects. All of the methods forcing teachers to choice the students in groups that include two to six members with different knowledge levels, high, average, and low doer; boys and girls; Anglo, black, Hispanic students, and mainstreamed academically disable students as well as normal classmates (Slavin, 1985 as cited in Wang, 2009).

Cooperative learning tries to make the student-centered classroom in which all the students contribute in group work, and student trust on each other to complete the task. The teacher plays the role as a mediator and tries to shift the responsibility to the students while holding them liable (Wang, 2012).

Cooperation is working together to attain shared goals within cooperative condition, individuals seek issues that are helpful to themselves and to all other group members (Prveen, Tariq Mohammad, Mahmood, \& Arif, 2011). Ideally, cooperative learning empowering both teachers and learners. It teaching them to structure their own goals and their own learning (Sapon-Shavin, 1994). It needs the situation in which teachers feel valued, trusted, and empowered to design and shape their classes and curricula as they see fit (Kohn, 1992, as cited in Sapon-Shevin, 1994)."Cooperative learning develops resolution skills among students. It creates better attitudes toward school, the learning process and the 
classmates. Cooperative learning improves collaborative ability among students, increases self-esteem and interpersonal skills"' (Clemen\& Hampton, 1994 as cited in Zarei, 2012, p.20).

Cooperative learning is necessary for making inclusive classroom environments that meet the needs of all students, because it takes the heterogeneity in to account, improving peer support and connection (Magre \& Joshi, 2013). It is practical as an instructional method in which small groups are considered to maximize students- working together in groups to attain shared goals (Johnson\& Johnson, 1999 as cited in Simpson, 2012). In cooperative learning classes, students working in heterogeneous-ability groups on clearly given tasks with the hope that they will be rewarded on the basis of group accomplishment (Johnson, Maruyama, Johnson, Nelson, \& Skon, 1981; Slavin, 1990, 1996 as cited in Hancock, 2004).

Cooperative learning techniques prompts some skills in learning as follow:

- Develop learners learning, and academic achievement

- Promote students retention

- Support learners to improve skills in oral communication

- Help learners to improve higher order thinking skills

- Create better natural motivation to learn

- $\quad$ Provide the same participation and simultaneous connection (Davis \& Murrill, 1994; Philiphs, et. al., 2004 as cited in Khader,2011, p.204)

\subsection{Problems with Cooperative Learning}

One of the problem which teachers have about the use of pair work (cooperative activity), especially in foreign language (FL) classes is that learners share their first language rather than $\left(\mathrm{L}_{2}\right)$ in their pair work (Carless, 2008 as cited in Srorch, 2012). In many classes teachers resist to use cooperative strategies in their classes because, they are afraid to lose the control of the classes, they don't prepare materials for using in their classes or teachers are not enough trained in cooperative teaching techniques (Zarei, 2012).

\section{Method}

3.1 Aims of Study

Accordingly, the main focus of the present study was on language learners' WTC and the kind of feedback they receive. Based on such assumption the following research questions were suggested:

Q1) Does immediate corrective feedback have a significant effect on intermediate EFL learners' WTC?

Q2) Does delayed corrective feedback have a significant effect on intermediate EFL learners' WTC?

\subsection{Participants}

To accomplish the objectives of the study, the researcher chose 45 females intermediate Iranian EFL learners through available sampling to participate in this study. The participants were selected from among 60 EFL language learners who were studying at a language school, in Kermanshah, a city in west of Iran. They were both high school and university students. It should be mentioned that, the participants' age ranged between 16 to 22 and their first language was Persian.

\subsection{Instrument}

In order to measure the learners' WTC levels, a modified version of the Likert-type questionnaire developed by MacIntyre (2001) that was changed by Pourya Baghaei and Ali Dourakhshan for using in Iranian context (2012) was distributed among the participants. The questionnaire includes 20 items relevant to the factors contributing to WTC in learning a FL. The questionnaire items were translated into participants' native language (Persian) to avoid any possible misunderstandings and to increase the validity of responses. This questionnaire ranges from strongly disagree (1) to strongly agree (5). The learners were asked to indicate their responses to the items across the continuum

\subsection{Procedure}

To conduct the present study and to select the main sample for the study, 45 of the students within the range of intermediate level of proficiency that were roughly selected according to their previous grades and their assigned level in the language school were chosen as the available sample and participants of the study. After that they were divided to three equal groups:

Experimental group 1. immediate feedback,

Experimental group 2. Delayed feedback and Control group.

As the first step, WTC questionnaire was administered to all groups. To begin the treatment, the teacher corrected her students' errors in group 1 (immediate feedback group) immediately. In other words, she employed different types of corrective feedback whether implicit or explicit. Implicit corrective feedback included recasts and prompts. Prompts also involved clarification request, metalinguistic feedback, elicitation and repetition. Some examples are presented below: 
Student: The patient sent to Tehran.

Teacher: The patient was sent to Tehran.

Prompt:

1-Clarification request:

Student: The patient sent to Tehran.

Teacher: Sorry what?

2-Metalinguistic feedback:

Student: The patient sent to Tehran.

Teacher: You need an auxiliary verb because that sentence is passive.

3-Elicitation:

Student: The patient sent to Tehran.

Teacher: Try that sentence once more.

4-Repetition:

Student: The patient sent to Tehran.

Teacher: The patient sent?

And explicit correction:

Student: The patient sent to Tehran.

Teacher: That's not right. you have to say, the patient was sent to Tehran.

The treatment for the group 2 (delayed feedback group) involved writing the students' errors and giving them corrective feedback when the students finished their tasks. The teacher explained their errors to the class in details. For the control group, the routine procedures proposed by New Headway intermediate presented in the teachers' guide were followed. New Headway consisted of some common class activities such as reading, listening and speaking. In reading section, the students read the texts and looked up words in dictionary and teacher explained some vocabularies and expressions then they memorized vocabularies. The speaking section consisted of a set of observation tasks based on teaching pragmatics. These tasks asked the students to use for example the politeness function to offer a suggestion or ask a request. The format of these tasks was designed in conversational formats.

At the end, the participants of control group checked their answers with a listening item, which was produced by native speakers. In other words, the students' answers were compared with the native speakers' answers. After about 12 sessions WTC questionnaire was given to the participants as posttest.

As the sampling procedure of this study was available sampling, it was conducted in quasi-experimental mode with the inclusion of two experimental and one control groups. The independent variables of this study were immediate corrective feedback and delayed corrective feedback, and the dependent variable of the study was EFL learners' WTC.The design of this study was pretest-posttest control group design.

\subsection{Data Analysis}

To answer the research questions, One-Way ANOVA procedure followed by Post- Hoc Scheffe test was run . This test provided analysis of variance for the dependent variable (i.e. WTC) by the specific factor (i.e. types of feedbacks) to scrutinize which type of feedback was more beneficial for improving the participants' WTC. Finally, to examine the participants' possible progression from pretest to posttest, three sets of Paired Samples T-tests were run to the results of pre and posttest of each group.

\section{Results}

The result of the study is presented as below.

\subsection{Descriptive Statistics for the Pre-Test Scores of the WTC Questionnaire}

At the beginning of the study, all the 45 participants participated in the pre-test. The main goal was to set up a baseline measurement from which the participants' achievements on the post-test could be examined and explained. Table 1 and 2 reveal the results of One-Way ANOVA used to analyze the participants' scores in the pretest of WTC. 
Table 4.1 Group Statistics for the Pre- Test Scores of the Three Groups

\begin{tabular}{|c|c|c|c|c|c|c|c|c|}
\hline \multicolumn{9}{|l|}{ Pretest scores } \\
\hline & \multirow[t]{4}{*}{$\mathrm{N}$} & \multirow[t]{4}{*}{ Mean } & \multirow{4}{*}{$\begin{array}{l}\text { Std. } \\
\text { Deviatio } \\
\mathrm{n}\end{array}$} & \multirow{4}{*}{$\begin{array}{l}\text { Std. } \\
\text { Error }\end{array}$} & $95 \%$ & Confidence & \multirow{4}{*}{$\begin{array}{l}\text { Minimu } \\
\mathrm{m}\end{array}$} & \multirow[t]{4}{*}{ Maximum } \\
\hline & & & & & \multicolumn{2}{|c|}{ Interval for Mean } & & \\
\hline & & & & & Lower & Upper & & \\
\hline & & & & & Bound & Bound & & \\
\hline Control group & 15 & 17.89 & 4.58 & 1.16 & 16.78 & 21.71 & 14.00 & 23.00 \\
\hline $\begin{array}{l}\text { Experimental } \mathrm{A} \\
\text { (immediate ) }\end{array}$ & 15 & 18.21 & 5.21 & 1.23 & 19.46 & 24.13 & 14.00 & 24.00 \\
\hline $\begin{array}{l}\text { Experimental B ( } \\
\text { delayed) }\end{array}$ & 15 & 18.11 & 5.12 & 1.30 & 21.32 & 23.37 & 15.00 & 25.00 \\
\hline Total & 45 & 18.63 & 5.20 & .67 & 21.28 & 23.97 & 14.00 & 25.00 \\
\hline
\end{tabular}

The descriptive Table 2 revealed the sample size, the mean, the standard deviation, and the standard error for all the three groups at the beginning of the study. For WTC, the means for the control group, experimental (A) and experimental $(\mathrm{B})$ groups were $\left(\mathrm{X}^{-}\right.$control group $\left.=17.89\right),\left(\mathrm{X}^{-}\right.$experimental group $\left.(\mathrm{A})=18.21\right)$ and $\left(\mathrm{X}^{-}\right.$experimental group (B) $\left.=18.11\right)$, respectively. In addition, the degree of variation of the scores for the experimental group (B) (SD experimental group (A) $=$ 5.21) was a little higher than the extent of dispersing of scores around the mean score for the experimental group (A) and the control group ( $\mathrm{SD}$ experimental group (B) $=5.12 ; \mathrm{SD}$ control group $=4.58$ ). The ANOVA examined whether these differences in the mean scores of the three groups were statistically significant before presenting the particular treatments to the experimental groups.

Table 4.2 One-Way ANOVA for the Pre- Test Scores of the Control and Experimental Groups

\begin{tabular}{llllll}
\hline & Sum of Squares & df & Mean Square & F & Sig. \\
\hline Between Groups & 46.433 & 2 & 23.217 & .854 & .431 \\
\hline Within Groups & 1549.500 & 57 & 27.184 & & \\
\hline Total & 1595.933 & 59 & & & \\
\hline
\end{tabular}

According to Table 2, there was no meaningful difference between the mean scores of the three groups in pre-test of WTC ( $\mathrm{p} \geq .05)$. This meant that, the groups were almost at the same level regarding WTC at the beginning of the study. The following figure illustrates the three groups' performance on pre-test of WTC.

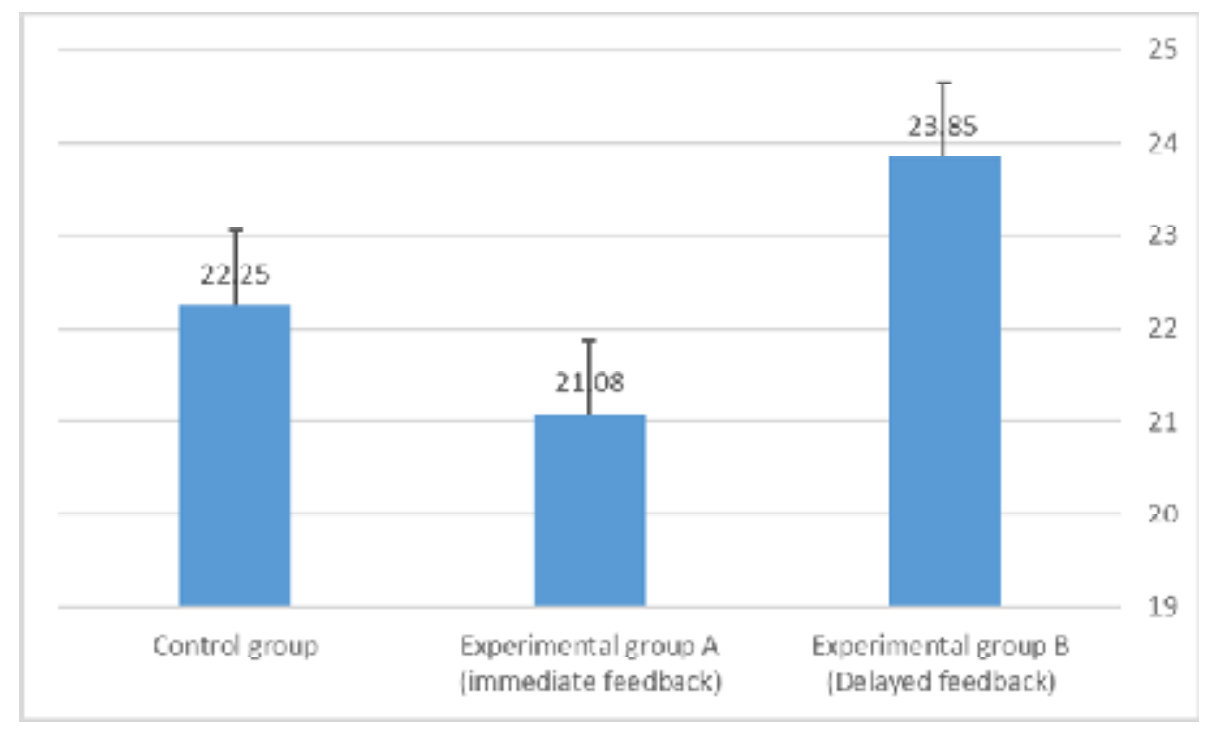

Figure 1. The three groups' performance on pretest of WTC

To answer the research questions, One-Way ANOVA procedure was run that produced a One-Way Analysis of variance for the quantitative dependent variable that was posttest of WTC by the independent variable (types of corrective feedback). ANOVA was used to test the hypothesis that the means of the three groups were the same on posttest of WTC. Since analysis of variance is sensitive to deviation from normality, the uniformity of the variances for the three 
groups was assessed for the results of the posttest, too. It was assumed that each group was an independent random sample from a normal population. To test this assumption, Levene's homogeneity of variance test was run for the results of the post-test.

Table 4.3 Test of Homogeneity of Variances for the Post Test Scores

\begin{tabular}{lccc}
\hline posttest scores & & & \\
\hline $\begin{array}{l}\text { Levene } \\
\text { Statistic }\end{array}$ & df1 & df2 & Sig. \\
\hline 3.068 & 2 & 57 & .058 \\
\hline
\end{tabular}

The test of homogeneity of variance revealed that the variances of the three groups were identical for the post-test of WTC. It was shown that the levene's test was not significant for the posttest scores; $F_{\text {posttest }}(2,57)=3.068, p=.058-$ at the .05 alpha level. After confirming the homogeneity of variances, ANOVA was run to the results of the WTC posttest. The descriptive statistics for the WTC posttest is presented in the following table:

Table 4.4 Descriptive Statistics for the Posttest Scores

\begin{tabular}{|c|c|c|c|c|c|c|c|c|}
\hline \multicolumn{9}{|l|}{ posttest scores } \\
\hline & \multirow[t]{2}{*}{$\mathrm{N}$} & \multirow[t]{2}{*}{ Mean } & \multirow[t]{2}{*}{$\begin{array}{l}\text { Std. } \\
\text { Deviation }\end{array}$} & \multirow[t]{2}{*}{$\begin{array}{l}\text { Std. } \\
\text { Error }\end{array}$} & \multicolumn{2}{|c|}{$\begin{array}{l}\text { 95\% Confidence Interval for } \\
\text { Mean }\end{array}$} & \multirow[t]{2}{*}{$\begin{array}{l}\text { Minimu } \\
\mathrm{m}\end{array}$} & \multirow[t]{2}{*}{ Maximum } \\
\hline & & & & & $\begin{array}{l}\text { Lower } \\
\text { Bound }\end{array}$ & Upper Bound & & \\
\hline Control group & 15 & 19.01 & 5.22 & 1.26 & 21.75 & 22.04 & 18.00 & 25.00 \\
\hline $\begin{array}{l}\text { Experimental } \mathrm{A} \\
\text { (immediate ) }\end{array}$ & 15 & 24.16 & 5.86 & 1.31 & 26.90 & 24.39 & 18.00 & 25.00 \\
\hline $\begin{array}{l}\text { Experimental B ( } \\
\text { delayed) }\end{array}$ & 15 & 22.48 & 5.44 & .83 & 27.65 & 23.14 & 20.00 & 24.00 \\
\hline Total & 45 & 24.81 & 5.640 & .72 & 24.35 & 23.27 & 18.00 & 35.00 \\
\hline
\end{tabular}

The results of the post-test disclosed that the Mean of the (control group, $\mathrm{X}^{-}=19.12$ ), Mean (experimental group (A), $\mathrm{X}^{-}$ =24.16), and the Mean of the (experimental group $\left.(B), \mathrm{X}^{-}=22.48\right)$, differed significantly. The significance value of the $F$ test in the ANOVA table was less than (.05). Thus, the hypotheses that average assessment scores of the WTC

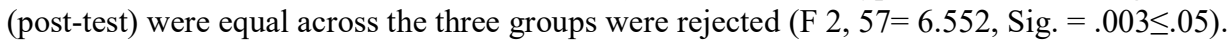

Table 4.5 ANOVA for the Results of the WTC (Post-Test)

\begin{tabular}{|c|c|c|c|c|c|}
\hline \multicolumn{6}{|l|}{ ANOVA } \\
\hline \multicolumn{6}{|l|}{ posttest scores } \\
\hline & Sum of Squares & $\mathrm{df}$ & Mean Square & $\mathrm{F}$ & Sig. \\
\hline Between Groups & 350.833 & 2 & 175.417 & 6.552 & .003 \\
\hline Within Groups & 1526.150 & 57 & 26.775 & & \\
\hline Total & 1876.983 & 59 & & & \\
\hline
\end{tabular}

The following figure illustrates the means plot for the results of the posttest of WTC.

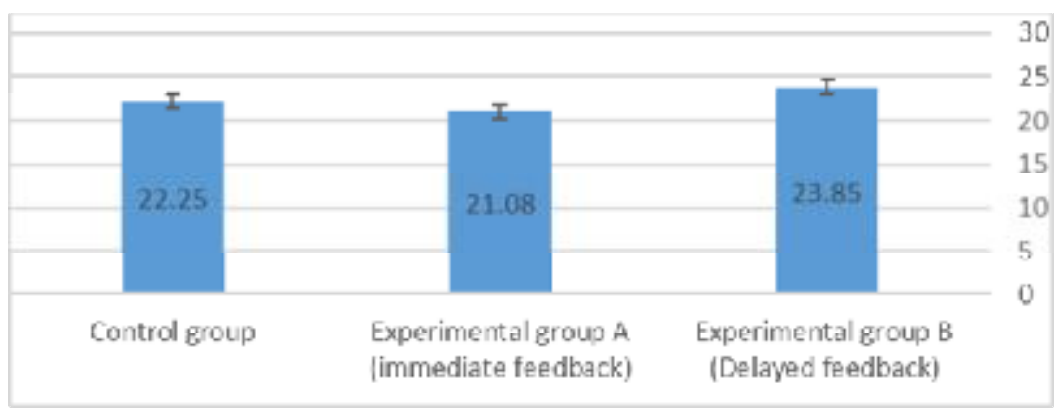

Figure 2. Means plot for the results of the WTC (Post Test) 
The first research question enquired if immediate corrective feedback has a significant effect on EFL learners' WTC.

In general, $F$ statistics firmly settled that there were statistically significant differences among the three groups' means, and means plots exposed the position of these differences. The participants of the experimental group (A) outperformed their counterparts including experimental group (B) and the control group.

After it was revealed that the groups differed in some way, post- hoc test displayed more about the structure of the differences. In other word, doing multiple comparisons Post- hoc test (Scheffe) was employed for comparing the means of the three groups.

Table 4.6 Multiple Comparisons for the Results of the Posttest

Dependent Variable: posttest scores

Scheffe

\begin{tabular}{|c|c|c|c|c|c|c|c|c|c|c|}
\hline \multirow[t]{2}{*}{ (I) groups } & & & \multirow[t]{2}{*}{ (J) groups } & & & \multirow{2}{*}{$\begin{array}{l}\text { Mean Difference } \\
(\mathrm{I}-\mathrm{J})\end{array}$} & \multirow{2}{*}{$\begin{array}{l}\text { Std. } \\
\text { Error }\end{array}$} & \multirow[t]{2}{*}{ Sig. } & \multicolumn{2}{|c|}{$95 \%$ Confidence Interval } \\
\hline & & & & & & & & & $\begin{array}{l}\text { Lower } \\
\text { Bound }\end{array}$ & $\begin{array}{l}\text { Upper } \\
\text { Bound }\end{array}$ \\
\hline \multirow{2}{*}{\multicolumn{3}{|c|}{ Control group }} & $\begin{array}{l}\text { Experimental } \\
\text { (immediate) }\end{array}$ & & A & $-5.25000^{*}$ & 1.63629 & .009 & -9.3628 & -1.1372 \\
\hline & & & $\begin{array}{l}\text { Experimental } \\
\text { delayed) }\end{array}$ & B & ( & $-5.00000^{*}$ & 1.63629 & .013 & -9.1128 & -.8872 \\
\hline \multirow{2}{*}{$\begin{array}{l}\text { Experimental } \\
\text { (immediate ) }\end{array}$} & & A & Control group & & & $5.25000^{*}$ & 1.63629 & .009 & 1.1372 & 9.3628 \\
\hline & & & $\begin{array}{l}\text { Experimental } \\
\text { delayed ) }\end{array}$ & B & ( & .25000 & 1.63629 & .988 & -3.8628 & 4.3628 \\
\hline \multirow{2}{*}{$\begin{array}{l}\text { Experimental } \\
\text { delayed ) }\end{array}$} & B & ( & Control group & & & $5.00000^{*}$ & 1.63629 & .013 & .8872 & 9.1128 \\
\hline & & & $\begin{array}{l}\text { Experimental } \\
\text { (immediate) }\end{array}$ & & A & -.25000 & 1.63629 & .988 & -4.3628 & 3.8628 \\
\hline
\end{tabular}

*. The mean difference is significant at the 0.05 level.

As it is displayed in Table 6, the highest mean difference was reported between "experimental group (A)" and the "control group" with mean difference of (5.25). On the other hand, the lowest mean difference was shown between the two experimental groups (mean difference=.25). As it is shown in Table 4.6, "experimental group (A)" outweighed the other two groups in relation to their WTC (mean experimental group (A) $=29.65 ; \mathrm{SD}=5.86$ ). The second research question investigated whether delayed corrective feedback has a significant effect on EFL learners' WTC.

The above findings revealed that delayed corrective feedback significantly affected EFL learners' WTC. Based on the findings of the analyses, in the second place, the "experimental group (B)" performed better than the "control group". In other words, the "control group's" performance was lower than the other two groups.

\section{Discussion}

In language teaching studies, many contributing factors have been identified which can have facilitative or impedingrole in the process of language learning. Some factors are closely connected to the role of teacher in the classroom. Among these factors various types of feedback have been gained an important position. "Feedback generally refers to the listeners or readers' response given to the learners' speech or writing" (Duly, Bust \& Krashen, 2006). This indicates that feedback refers to the information or suggestion that the teacher as a listener or as reader gives or provides to his learners speaking performance or written production. A definition suggested by Mory( 2002): "Feedback is the information presented to the learner after any input with the purpose of shaping perception of the learner" (p.7). Moreover, he states that feedback determines the comparison between the learners and the teachers intended answer.

The other variable of this study was WTC. Considering the definition of WTC it can be applied both for first language acquisition and second language learning. In first language acquisition, it is defined as a stable predisposition toward communication when free to choose to do so (McCoskey\& Baer, 1985). Thus, WTC which is deemed to affect the frequency of interaction (Clement, Baker, \&MacIntyre, 2003) can contribute to second language acquisition and is considered as an important component of modern L2 pedagogy (MacIntyre et al., 1998). The findings of this study show that these three techniques of scaffolding can have positive effect on promoting WTC.

In this study attempts were made to investigate the effects of immediate and delayed feedback on language learners' WTC and anxiety. It was perceived that "immediate corrective feedback" and "delayed corrective feedback" significantly influenced Iranian EFL learners' WTC and anxiety. The study revealed that "immediate corrective feedback" improved the participants' WTC and anxiety better than "delayed corrective feedback". 
The results of this study subscribe to this point that feedbacks can have facilitative role on language learning process. Because, they can reduce the level of anxiety and increase the level of WTC among language learners. These findings are in line with the results of following studies.

Ferreira et al. (2007) investigated two approaches to corrective feedback in language education: the GAS strategy (i.e., Giving Answers Strategy) in which the instructors use the right answer, and the PAS strategy (i.e., Prompting Answers Strategy) in which instructors encourage language learners to use right answer. Their findings indicated that GAS was employed more often than PAS; however, PAS was considered as a variable which can improve student Performances in the classroom significantly (as cited in Thurlings et al., 2013).

Goodman et al. (2008) and Scheeler et al. (2010) advised that feedback should be specific and corrective. An overwhelming majority of these (student) teachers indicated $90-100 \%$ of the appropriate performance in short term and in the 2010 research, Scheeler et al.'s participants showed their appropriate performance in the long term as well as in various contexts in $75-100 \%$ of the cases (as cited in Thurlings et al., 2013). In Auld et al.'s (2010) and Rodriguez et al.'s (2009) studies, the students also showed an increase of their desired behaviour (e.g., less interrupting in Rodriguez et al., as cited in Thurlings et al., 2013).

This results of this study are in line with what Carroll and Swain (1993); Ellis et al (2006) and Sheen (2006) claimed that learners would benefit from immediate feedbacks, whereas other researchers, such as Lyster and Ranta (1997), Oliver (2000), and Oliver and Mackey (2003) suggested that for particular forms in particular contexts feedback is effective when it is delayed corrective feedback.

\section{Conclusion}

In communicative era of languge teaching, speaking gained an important position among other skills.As Egan(1999) states, speaking skill is the main component of second language teaching and learning, but in recent years, it has been neglected for a number of reasons.in Teaching English as a Foregn Language(TEFL), speaking is considered as an interactive productive skill which focuses on receiving, processing and transferring intended meanings in spoken form of language.(McDonough \& Shaw 1993;Brown 1994).

Based on the above points, Finding and designing appropriate techniques for teaching speaking skill are of great importance. Subsequently, in present study, attempts were made to investigate the effects of immediate and delayed feedback on Iranian EFL leaners WTC.According to the obtained results, it can be concluded that, the teachers and material developers should pay attention to these two techniques and employ them for the educational purposes. The implication of this study for language teacher is that they should allocate a lot of time of the class to employing different kinds of techniques in the classroom for teaching speaking. However, it should be noted that various types of oral feedback can have constructive effects on promoting learners' ability in language learning. As the results show teacher should try to employ them very carefully.

Concerning the nature of these two techniques which is cooperative, language learners should pay special attention to the key role of communicative and interactive activities in the classroom. Therefore, they should be very active in the classroom. Considering the scores of experimental groups in this study, language learners should be careful about their roles in the classroom. The results of this study can be helpful for material developers in a way that they should consider the role of teachers and language learners in the conversational classes. Instead of bolding the role of teachers they should try to give priority to the language learners and materials.

\subsection{Limitations and Future Study}

In order to make this study easier to perform, the group is selected only among female students. However, this might limit the generalizability of the findings to other groups.Also,this study was carried out with a small number of learners so this can decreases the generalizability of the results to all language learners.

This study was conducted based on a limited number of participants. So in the future more language learners should be assessed and also student's opinions about using immediate and delayed feedbacks may be asked. These feedbacks were conducted to promote WTC level of language learners, while they could be applied for other language skills such as reading.

\section{References}

Bashir, M., Azeem, M., \& Dogar, A. H. (2011). Factors effecting students' English speaking skills. British journal of arts and social sciences, 2(1), 34-50.

Brown, H. Douglas. (1994). Principles of language learning and teaching. 3rd edition. Englewood Cliffs, NJ: Prentice Hall Regents.

Bygate, M. 1987. Speaking. Oxford: Oxford University Press.

Carroll, S., \& Swain, M. (1993). Explicit and implicit negative feedback: An empirical study of the learning of linguistic generalizations. Studies in Second Language Acquisition, 15, 357-386.

Dörnyei, Z. (2005). The psychology of the language learner: Individual Differences in second language acquisition. Mahwah, NJ: Lawrence Erlbaum.

Dulay, H., Burt, M., \& Krashen, S. (1982). Language two. New York: Oxford University Press. 
Ellis, R. (2006). The study of second language acquisition. Oxford University Press.

Fulcher, G. (2003) Testing second language speaking. London: Longman.

Ferreira, A., Moore, J. D., \& Mellish, C. (2007). A study of feedback strategies in foreign language classrooms and tutorials with implications for intelligent computer-assisted language learning systems. International Journal of Artificial Intelligence in Education, 17(4), 389-422.

Goodman, J. I., Brady, M. P., Duffy, M. L., Scott, J., \& Pollard, N. E. (2008). The effects of “bug-in-ear”' supervision on special education teachers' delivery of learn units. Focus on Autism and Other Developmental Disabilities, 23(4), 207-216. http://dx.doi.org/10.1177/1088357608324713.

Harmer, J.(2000). The Practice of English Language Teaching. London: Longman.

Harmer, J.(2004). How to Teach Writing. Edinburgh Gate: Pearson Education Limited, Longman.

Kang, S.-J. (2005). Dynamic emergence of situational willingness to communicate in a second language. System, 33, 277-292. http://dx.doi.org/10.1016/j.system.2004.10.004

Levelt, W.J.M. (1989). Speaking: From intention to articulation. Cambridge, MA: MIT Press

Lightbown, P. M., \& Spada, N. (1999). How languages are learned. Oxford, UK: Oxford University Press.

Lightbown, P. M., \& Spada, N. (1990). Focus-on-form and corrective feedback in Communicative Language Teaching: Effects on second language acquisition. Studies in Second Language Acquisition, 12, 429-448.

Lyster, R., \& Ranta, L. (1997). Corrective feedback and learner uptake: Negotiation of form in communicative classroom. Studies in Second Language Acquisition, 19(1), 37-66.

MacIntyre, P. D., \& Charos, C. (1996). Personality, attitudes, and affect as predictors of second language communication. Journal of Language and Social Psychology, 15(1), 3-26. http://dx.doi.org/10.1177/0261927X960151001

MacIntyre, P. D. (2002). Motivation, anxiety and emotion in second language acquisition. In P. Robinson (Ed.), Individual differences and instructed language learning (pp. 45-68). Philadelphia, PA: John Benjamins.

Macintyre, P. D., MacMaster, K., \& Baker, S. C. (2001). The convergence of multiple models of motivation for second language learning: Gardner, Pintrich, Kuhl, and McCroskey. In Z. Dörnyei \& R. Schmidt (Eds.), Motivation and second language acquisition (Technical Report \#23, pp. 461-492). Honolulu: University of Hawaii, Second Language Teaching and Curriculum Center.

MacIntyre, P. D., Baker, S. C., Clément , R., \& Donovan, L. A. (2007). Talking in order to learn: Willingness to communicate and intensive language programs. Canadian Modern Language Review, 59(4), 589-607. doi: $10.3138 / \mathrm{cmlr} .59 .4 .589$

Mackey, A. (Ed.). (2003). Conversational interaction in second language acquisition: A collection of empirical studies. Oxford: Oxford University Press.

Nunan, K. (1991). Theories of communication. Retrieved from http://lali24saly.wikispace.com/speaking/theory

Oliver, R. (2000). Age differences in negotiation and feedback in classroom and pairwork. Language Learning, 50, 119-151.

Scheeler, M. C., Congdon, M., \& Stansbery, S. (2010). Providing immediate feedback to co-teachers through bug-in-ear technology: An effective method for peer coaching in inclusion classrooms. Teacher Education and Special Education, 33(1), 83-96. http://dx.doi.org/10.1177/0888406409357013.

Thurlings, M., Vermeulen, M., Kreijns, C., Bastiaens, T. J., \& Stijnen, P. (2013). Development of the Teacher Feedback Observation Scheme: Evaluating the quality of feedback in peer groups. Journal of Education for Teaching, 38(2), 193208. http://dx.doi.org/10.1080/02607476.2012.656444.

Wang, L. (2005). Technology integration in foreign language teaching demonstrates the shift from a behavioral to a constructivist learning approach. THE Journal Online. Retrieved on May 26, 2005 from http://www.thejournal.com/magazine/vault/A5357C.cfm

Yashima, T. (2002). Willingness to communicate in a second language: The Japanese EFL context. Modern Language Journal, 86, 54-66. 


\section{A Sample of Translated WTC Questionnaire}

سنجش اشتياق برقرارى ارتباط در يك زبان بيعانه:

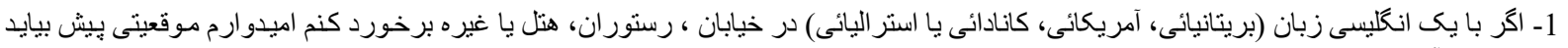
كه بتو انم با آنها صحبت كنم. نكان

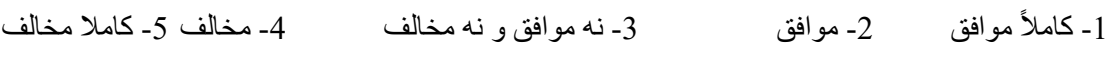

2- اكر با يكى انكليسى زبان در خيابان، رستوران، هنل يا غيره برخورد كنم بهانه اى بيدا مى كنم و با آنها حرف مى زنم.

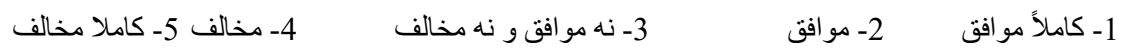

3- اكر با يك انكليسى زبان كه در كثور من به خاطر ندانستن زبان ما با مشكل مو اجه شده، برخورد كنم از اين فرصت استفاده مى كنم و باو حرف مسى

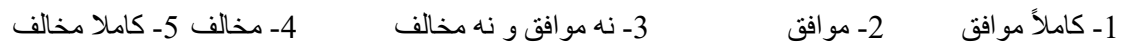

4- مشتاقم كه انكليسى زبانان را همر اهى كنم و به صورت مجانى يك روز راهنماى كردشكرى آنها باشم.

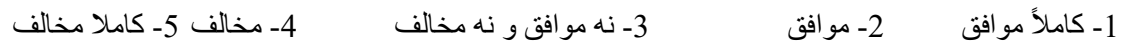
5- مشتاقم كه با انكليسى زبان ها (بريتانيائى، آمريكائى، كانادائى يا استر اليائى) حرف بزنم.

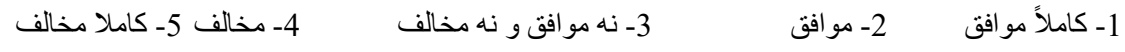
6- اكر كسى مر ا به يك انكليسى زبان معرفى كند، دوست دارم كه توانايى هايم را براى برقر ارى ارتباط با او به زبان انكليسى به كار بكيرم.

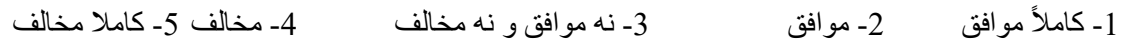

